УДК 330.322 .01

\title{
РИЗИКИ ІНВЕСТИЦІЙНОї ДІЯЛЬНОСТІ
}

๑ Л. П. Шендерівська, ст. викладач, О. В. Копайгора, НТУУ «КПІ», Київ, Україна

Проанализированы направления государственной политики, которые повышают риск инвестиционной деятельности в издательско-полиграфической отрасли. Обоснованы факторы выбора основного технологического оборудования направленные на минимизацию рисков.

The directions of government policies that increase the risk of investment in publishing and printing industry are analyzed. The choice of main factors of process equipment to minimize risks is grounded.

\section{Постановка проблеми}

Розвиток підприємства потребує інвестицій. Поліграфічне виробництво характеризується високою капіталомісткістю. Український ринок споживачів поліграфічного обладнання привабливий для іноземних виробників з причини нерозвиненості вітчизняного поліграфічного машинобудування; як альтернатива комерційному кредитуванню розвивається лізингова діяльність, що створює сприятливі умови для технічного переоснащення друкарень. Використання лише власних ресурсів уповільнює процеси оновлення, приросту капіталу. Висока вартість позикових коштів, тривалий термін окупності, нестабільність ринкового середовища негативно впливають на ймовірність реалізації інвестиційних проектів, тобто актуалізують питання дослідження ризиків.

\section{Аналіз попередніх досліджень}

Інвестиційні ризики належать до сфери наукових інтересів
В. В. Вітлінського, С. І. Наконечного, іх прояви у видавничополіграфічній галузі вивчають А. М. Штангрет, Б. В. Дурняк, Л. А. Швайка, напрями вирішення проблем інвестиційної діяльності у книговидання та поліграфії обґрунтовує Х. Я. Яремик, розвитку інвестиційної діяльності галузі присвячені праці О. Афоніна, Я. Котляревського, М. Тимошика тощо. Проте, незважаючи на значну кількість праць стосовно економічних проблем поліграфії та видавничої сфери, питання ризиків інвестування у поліграфію недостатньо розроблене.

\section{Мета роботи}

Вивчення ризиків інвестиційної діяльності у поліграфічній галузі для забезпечення інформаційної бази розробки планів інвестицій.

\section{Результати проведених досліджень}

Розробка інвестиційної стратегії повинна базуватися на вивченні потреб замовників, конку- 
ренції, можливості і доцільності впровадження інноваційних розробок тощо. Кризові явища викликають структурні зміни ринкового середовища, тобто, загрози для одних суб'єктів створюють можливості для інших. Наслідком економічного спаду 2008 року є згортання діяльності суб'єктів поліграфічного сектору, продаж обладнання тощо. Тобто ринок вторинного устаткування істотно пожвавився, що створює сприятливі умови для технічного переоснащення підприємств прогресивною технікою з істотними ціновими знижками.

Плануючи оновлення виробничої потужності, при оцінюванні альтернатив необхідно орієнтуватися на економію питомих витрат, тобто враховувати потенціал розвитку ринку, умови кредитування, універсальність техніки, енергоспоживання, вартість технічного обслуговування, ціну, дефіцитність витратних матеріалів, додаткові кошти на навчання персоналу.

Отже, вибір основного технологічного обладнання доцільно здійснювати з урахуванням таких факторів:

- відповідність ринковим потребам. Використання високопродуктивної техніки економічно доцільне для виготовлення великотиражних замовлень; оперативної поліграфії, насамперед газет;

- можливості кооперації з іншими підприємствами для підвищення ступеня інтенсивного використання устаткування;

- інноваційність, прогресивність техніки, що створить конкурентні переваги підприємству;

- ефективність інтеграції у технологічний цикл підприємства, автоматизовану систему управління виробництвом;
- зносостійкість, можливості сервісного обслуговування, встановлення;

— простота в обслуговуванні, умови праці;

- екологічні параметри.

Ріст соціально-економічної та політичної невизначеності, наслідки кризи 2008 року, нестабільність та неоднозначність трактування законодавства нашої країни створюють передумови для виникнення значних ризиків у здійсненні господарської діяльності, зокрема інвестиційної. Непрогнозованість більшості подій та процесів, безпосередньо пов'язаних із провадженням господарських операцій, не є прогнозованими, що ускладнює прийняття управлінських рішень та зумовлює імовірність настання ризику [1].

У більшості економічних та виробничих секторів України діє правило відкритості до іноземних інвестицій, проте виключенням $€$ такі галузі, як телекомунікації та видавнича справа. За даними Нацбанку, спостерігається ріст притоку іноземних інвестицій в Україну, які у 2010 році складали на $25 \%$ більше, ніж у попередньому. За даними Групи Світового банку українські виробничі сектори відкриті до іноземного інвестування на сто відсотків, у той час як ЗМІ України на 15 , а видавнича справа на 30 відсотків [2]. На мотивацію інвестора впливає рівень політичної, економічної, екологічної стабільності. Основний ризик інвестиційної діяльності - ринковий, тобто, попит нижче від запланованого. Неприйнятний рівень означає збитковість, неможливість забезпечити самоокупність. Якісна, кількісна оцінка 
ризиків має бути превентивною. Систематизований підхід до вирішення цього питання забезпечує класифікація ризиків.

За масштабами розрізняють загальноекономічний ризик та індивідуальний. Перший виникає внаслідок співіснування та взаємодії усіх сфер економіки, а також спричиняється зовнішніми умовами реалізації інвестиційного проекту. Як правило, існує на державному чи галузевому рівні. Індивідуальний ризик зумовлений особливостями певного інвестиційного проекту, зокрема, низькою якістю обґрунтування планів [3].

Для зменшення ступеня невизначеності мають враховуватися такі чинники: політичний, загальноекономічний, правовий, технічний, учасників проекту, фінансовий, маркетинговий та екологічний ризики [4].

Політичні інвестиційні ризики можуть бути зумовлені як зовнішніми, так і внутрішніми факторами. Членство України у СОТ спрощує забезпечення вітчизняних підприємств імпортним обладнанням, матеріалами. Але стримуючим фактором є сучасні зміни у галузі кредитування - заборона кредитів в іноземній валюті. У межах країни політичні ризики спричиняються перш за все недосконалістю законодавства. Нежорстке покарання за порушення авторських прав залишає невирішеною проблему піратства.

Несприятливим фактором може бути громадська політика. Для прикладу, влітку 2011 року понад 800 редакцій регіональних газет та журналів України солідарно заявили про намір у найближчі дні розпочати акції протесту, спрямовані на захист їх законних прав та інтересів. Мотивація - блокування Міністерством економічного розвитку та торгівлі, Міністерством інфраструктури України впорядкування взаємин редакцій та державних підприємств-монополістів, а також запровадження ринкових відносин у галузі видавництва [5].

Правовий ризик інвестування тісно пов'язаний із політичним, спричиняється відсутністю правового регулювання або зміною положень законів, інших нормативно-правових актів, що можуть посилити ступінь невизначеності законодавчо зумовлених особливостей впровадження інвестиційного проекту. Загрозою для розвитку видавничо-поліграфічних організацій $\epsilon$ норма Податкового кодексу України (яка набула чинності з 2011 року) про заборону включати до складу валових витрат товари, отримані від платників єдиного податку.

Загальноекономічні ризики $€$ одними 3 найпоширеніших у видавничій галузі. Державна підтримка у формі фінансування, надання пільг у сфері книговидання не має систематичного характеру. Недостатньо вивчається, відповідно не враховується адекватно в економічній політиці реальний стан книжкового ринку. Фактором економічного ризику інвестування $€$ низька, переважно за ціновим критерієм, конкурентоздатність української книжкової продукції, порівнюючи з російською.

До внутрішніх чинників виконання інвестиційних планів належать якість проектування, 
технічне забезпечення, обрана технологія. Природою технічних ризиків є порушення технології виробництва, функціонування устаткування, результатом незаплановане зменшення виробництва, збільшення браку.

Певний ступінь невизначеності притаманний поведінці учасників проекту, структурі, методам управління. Важливе значення має корпоративна етика.

Фінансові ризики виникають внаслідок зменшення обсягів фінансування, порушення надходження коштів від реалізації товарів та послуг тощо [4]. Невисока прибутковість книжкової продукції, великий термін реалізації в умовах економічної нестабільності негативно впливають на платоспроможність суб'єктів галузі.

Маркетинговий ризик виникає при помилковому виборі ринкового сегменту, маркетингової стратегії, оцінюванні конкурентного середовища тощо. Стримуючим фактором інвестування у книговидання $є$ нерозвиненість збутової мережі. Для формування асортименту, затребуваного читачами, необхідно підвищувати ефективність функціонування дистрибуційної ланки, зокрема шляхом належного інформаційного забезпечення.

Поліграфічне виробництво не $є$ екологічно безпечним. При розробці, реалізації інвестиційних проектів необхідно передбачати системи промислової вентиляції, знешкодження хімічних реагентів (відходів).

Серед опрацьованих джерел інформації про інвестиційний ринок існує узагальнююча кла- сифікація ризиків інвестування, що акумулює основні підходи до класифікації та уніфікувала види ризиків.

Згідно цієї класифікації за джерелами виникнення виділяються господарський ризик, ризик, пов'язаний з особистістю людини, та ризик, спричинений факторами природи. Залежно від ступеня можливості усунення ризики бувають несистематичними (специфічний вид ризику) та систематичними (ринковий) [6]. Виходячи з того, наскільки ризик впливає на стан підприємства, виділяються катастрофічний (в одному з 1000 випадків може бути втрачене все вкладене майно), критичний (в одному зі 100 - валовий дохід) та припустимий (в одному із 10 - прибуток) ризики [7]. За сферою виникнення існує поділ ризиків на зовнішній та внутрішній. Постійний та тимчасовий ризики виділяють згідно ознаки тривалості впливу. За можливістю передбачення розрізняють прогнозований та не прогнозований ризики. Відповідно до можливих наслідків ризики бувають такі, в результаті настання яких підприємство зазнає економічних втрат, недоотримує запланований обсяг доходу, а також такі, внаслідок яких можливі як втрати, так і додаткові доходи. Щодо об'єкту виникнення виділяються ризики окремих фінансових операцій, різних видів фінансової діяльності, загальної фінансової діяльності. За можливістю страхування бувають ризики, що підлягають страхуванню, та такі, що не підлягають [6]. 


\section{Висновки}

Вивчення природи ризиків $€$ базисом для їх уникнення шляхом розробки стратегій розвитку на рівні підприємства, країни. Ризик інвестиційної діяльності у видавничо-поліграфічній галузі збільшується внаслідок неефективності таких напрямів державної політики:

1. Монетарна, як наслідок, має місце інфляція, зменшується попит на видавничо-поліграфічну продукцію.

2. Податкова, що проявляється у складності системи оподаткування, високому податковому навантаженні, збільшенні частки тіньової економіки.
3. Правова - нестабільність законодавчої, нормативної бази ускладнює прогнозування.

4. Кредитна - зменшення активності банківської системи у галузі надання позик.

5. Митна - складність митних процедур, що провокує нелегітимні виплати.

6. Громадська - низький ступінь авторитетності громадських організацій (громадськості), покликаних захищати інтереси галузей, населення.

Ці процеси не повинні розглядатися ізольовано по країні, з огляду на глобалізацію економічного простору.

1. Стратегічні проблеми підприємств видавничо-поліграфічної галузі в умовах нестабільного ринкового середовища [Електронний ресурс] / Л. Є. Довгань, Г. А. Мохонько // Національний технічний університет України. - К., 2010. - Режим доступу : http://www.confcontact.com/ 20101224/3_dovgan.htm. 2. www.radiosvoboda.org [Електронний ресурс]. К., 2011. - Режим доступу : http://www.radiosvoboda.org/content/article/2093593.html. - Група Світового банку оприлюднила звіт про інвестиційний клімат у світі. 3. Вітлінський В. В. Аналіз, оцінка і моделювання економічного ризику [Текст] / В. В. Вітлінський. - К. : ДЕМІУР, 1996. - 212 с. - ISBN 5-7763-2369-Х. 4. Бакаєв Л. О. Кількісні методи в управлінні інвестиціями : Навч. посібник / Л. О. Бакаєв. - К. : КНЕУ, 2000. - 151 с. - ISBN 966-574-154-3. 5. www.expres.ua [Електронний ресурс]. - К., 2011. - Pежим доступу : http://www.expres.ua/main/2011/06/29/47180. - Понад 800 регіональних газет готові розпочати страйк. 6. www.BukLib.net [Електронний ресурс]. - К., 2011. - Режим доступу : http://buklib.net/component/ option,com_jbook/task,view/Itemid,99999999/catid,84/id,873. - Класифікація ризиків. 7. Федоренко В. Г. Інвестознавство [Текст] : Підручник. - 3-тє вид., допов. / В. Г. Федоренко. - К. : МАУП, 2004. - 480 с: іл. - Бібліогр.: с 470-472. - ISBN 966-608-370-1. 8. Проблеми здійснення інвестиційної діяльності підприємств видавничо-поліграфічної галузі [Електронний ресурс] / Х. Я. Яремик // Львівська академія друкарства. - Л., 2011. - Режим доступу : http://www.confcontact.com/20111019/3_yaremik.htm. 9. Сучасні тенденції розвитку підприємництва у видавничо-поліграфічній галузі України / А. М. Штангрет, В.В.Шляхетко // Вісник економічної науки України - 2008. — № 2(14). - С. 160-162. — Бібліогр.: 4 назв. - укр. 